\title{
Droga do wiary poganki Rachab. Teologiczna lektura Joz 2,1-24
}

\section{The road to faith of pagan Rahab. Theological reading of Joshua 2,1-24}

Słowa klucze: JHWH; Rachab; wiara; Jerycho; nawrócenie; odpłata; mądrość.

Key words: JHWH; Rahab; faith; Jericho; conversion; retribution; wisdom.

Streszczenie. Historia nierządnicy Rachab umieszczona przez deuteronomistycznego redaktora w otwarciu księgi Jozuego funkcjonuje jako literacki i teologiczny klucz do interpretacji jednego z najbardziej doniosłych wydarzeń z dziejów narodu izraelskiego, którym jest podbój i podział ziemi kananejskiej. Figura Rachab została wkomponowana w epizod zdobycia pierwszego miasta Kanaanu - Jerycha, które w tekście księgi jest ukazywane jako symboliczna brama otwierająca Izraelitom drogę do przejęcia ziemi obiecanej im przez JHWH. W perspektywie teologii deuteronomistycznej obecnej w całym dziele Joz-2 Krl, Rachab staje się uniwersalnym paradygmatem beneficjenta Bożych obietnic, a szczególnie obietnicy wyzwolenia i ziemi. Poprzez swą niewzruszoną wiarę w moc i wierność JHWH (Joz 2,9b-11), poprzez swą mądrość życiową pozwalającą przetrwać najtrudniejsze próby, a także przynależność do najuboższej i najbardziej uciskanej klasy społecznej, Rachab staje się pierwszą osobą wyzwoloną i obdarowaną przez Boga. Jej status społeczny oraz pełna wiary i ufności relacja do Boga jest pokazana jako droga, którą winni podążać wszyscy Izraelici pragnący dostąpienia realizacji Bożych obietnic.

Abstract. The story of Rahab is reported in the first part of Joshua as the key to theological interpretation of the whole book. In its present context, this narrative is embedded in the account of the Israelite conquest of Jericho. Rahab is presented as a harlot, who hides and rescues two spies of Joshua from the king of Jericho. She acknowledges the power of the Lord and extracts from the spies the promise that she and her family will be saved when the Israelites overwhelm her city. The story contains no indication of what motivated Rahab to risk her life on behalf of spies. His action must be connected with her confession and affirmation of Yahweh's power and fidelity. Rahab's confession in Josh 2,9b-11 is overflowing with Deuteronomistic language and theology, and is regarded as a late element in pre-Deuteronomistic material. 
K sięga Jozuego należy do najbardziej wzniosłych świadectw biblijnej historiografii. Otwiera ona tak zwane dzieło deuteronomistycznej historii Izraela (Joz-2 Krl), o którym mówi się, że jest najstarszym i najbardziej wiarygodnym cyklem tradycji dokumentującym przedmonarchiczne i monarchiczne dzieje narodu wybranego. Ten zbiór ksiąg, który powstał w wyniku bardzo długiego i wieloetapowego procesu redakcji, nie jest tylko zwykłą rekonstrukcją konkretnych faktów z historii Izraelitów, lecz również ich głęboką teologiczną interpretacją. Redaktorzy tych ksiąg wywodzą się z jednego środowiska i działali prawdopodobnie już od czasu religijnej reformy króla Jozjasza, która została podjęta w ocalałym od inwazji asyryjskiej królestwie Judy w końcowych dziesięcioleciach VII przed Chr. (2 Krl 22-23), i byli aktywni aż do ostatnich dziesięcioleci VI wieku przed Chr., kiedy to niewola babilońska położyła kres nie tylko judzkiej państwowości i jerozolimskiemu kultowi, ale także mocno osłabiła jahwistyczny monoteizm w sercach wielu Izraelitów. W tym bolesnym okresie historii religijna elita żydowska, zarówno ta przesiedlona do dalekiej Mezopotamii, jak i ta, która okres niewoli przeżywała w obrębie Palestyny, postanowiła zająć się odbudową leżącej w gruzach izraelskiej państwowości, tożsamości narodowej, ale też form i miejsc kultu oraz zrębów rodzimych tradycji. Aby tego dokonać, najpierw trzeba było jednak podnieść z upadku wewnętrzne morale Izraelitów, odnowić ich ducha i przywrócić wiarę w zbawczą obecność Boga JHWH w ich życiu. I ci bowiem, którzy znaleźli się w niewoli, i ci, którym okupant pozwolił pozostać w ojczyźnie, zadawali sobie pytania o przyczynę tak dramatycznego dla Izraela biegu zdarzeń. Pytali o powody, dla których utracili ziemię gwarantowaną im przez Boże obietnice. Pytali dlaczego upadła dynastia dawidowa mająca Boże zapewnienie wiecznej stabilności (2 Sm 7). Pytali o przyczynę, dla której została starta z powierzchni ziemi ich narodowa duma - Jerozolima wraz z jej świątynią. Izraelici przygnieceni jarzmem niewoli zapytywali także czy ten stan rzeczy jest nieodwracalny i jak na ich nieszczęście i upokorzenie zareaguje ich Bóg - JHWH.

Przy rekonstrukcji biblijnych uwarunkowań historycznych i kulturowych okresu przedmonarchicznego trzeba pamiętać o jednej bardzo ważnej rzeczy. Otóż cały starożytny Bliski Wschód wiązał wszystko, cokolwiek działo się na ziemi, ze światem nadprzyrodzonym i wolą bogów. Nie inaczej postępowali Izraelici. Co więcej, ci ostatni legitymowali się szczególnie bliską więzią z własnym Bogiem, co do którego byli przekonani, że na przestrzeni dziejów wybrał ich spośród wędrownych hebrajskich plemion, dał wolność, kładąc kres niewoli w Egipcie, a następnie przez Mojżesza uformował z nich naród, nadał prawo i zawarł przymierze gwarantujące im własną ziemię, pokój i bezpieczeństwo. Jedynym warunkiem pozyskania tych dóbr i przywilejów była trwała lojalność i wierność względem ich narodowego Boga. Zasady wzajemnej relacji z JHWH 
zostały zawarte w ostatniej części Pięcioksięgu - Księdze Powtórzonego Prawa, które, zgodnie z biblijną rekonstrukcją dziejów, obwieścił ludowi w imieniu Boga sam Mojżesz w przeddzień podboju ziemi obiecanej. W świetle tej właśnie teologii wybrania Izraela i jego dwustronnego przymierza z JHWH duchowe elity wywodzące się z Południowego Królestwa Judy postanowiły odtworzyć i odpowiednio zinterpretować historyczne fakty dotyczące całego Izraela a mające miejsce pomiędzy zdobyciem ziemi kananejskiej a jej dwustopniową utratą wskutek inwazji wojsk asyryjskich (722 r. przed Chr.), a następnie babilońskich (586 r. przed Chr.).

Biblijna rekonstrukcja tego etapu dziejów ogniskuje się więc wokół tematu otrzymanej od Boga ziemi, która w następstwie odstępstwa religijnego i wielokrotnej apostazji Izraelitów na rzecz kultu Baala i Asztarte przeszła w ręce bezwzględnych najeźdźców mezopotamskich. Bogate dzieje palestyńskiej ziemi od czasów podboju Jozuego aż po rządy ostatniego króla judzkiego - Jojakina są ukazane również w perspektywie wiary a jednocześnie niewiary Izraelitów. Wiara w JHWH, w myśl deuteronomistycznych redaktorów ksiąg Joz-2 Krl, polegała na osobistym odkryciu i akceptacji zbawczych znaków Bożej obecności i mocy manifestowanych od momentu objawienia się JHWH Mojżeszowi na górze Synaj (Wj 3,1-4,18), poprzez wybawienie z niewoli egipskiej (Wj 5,1-15,21) aż po długi okres wędrówki przez pustynię (Wj 15,22-18,27; Lb 10,10-22,1). Wdzięczna i niezachwiana pamięć o tych nadzwyczajnych ingerencjach Boga winna, według szkoły deuteronomistycznej, stanowić podstawę wiary każdego Izraelity i prowadzić do trwałej wierności JHWH polegającej na sankcjonowaniu zasad przymierza oraz przestrzeganiu objawionego przez Niego prawa. Jego naczelną zasadą był wyłączny kult JHWH oznaczający radykalne odrzucenie jakichkolwiek innych bogów, wszelkich form i wyrazów politeistycznych religii oraz sposobu życia charakterystycznego dla pogańskich ludów Kanaanu (Wj 20,1-17; Pwt 4,1-7,26; 27,1-28,68). Tak zdefiniowana wiara była koniecznym warunkiem doświadczenia Bożej życzliwości i łaskawości oraz spełnienia Jego obietnic, spośród których tą najważniejszą było otrzymanie na własność ziemi w Palestynie. I odwrotnie. Odrzucenie JHWH jako jedynego Boga oraz pogwałcenie zasad promulgowanego przez Niego przymierza i prawa jest pokazane przez deuteronomistycznych teologów jako przyczyna braku Bożego błogosławieństwa i pomocy w konfrontacji zbrojnej z obcymi ludami (Joz 7,1-8,35), powód utraty ziemi zdobytej dzięki Bożemu zaangażowaniu się w kampanię Jozuego oraz źródło wszelakich nieszczęść a nawet śmierci (Pwt 28,15-68), której doświadczyło niewierne pokolenie Izraelitów podczas wędrówki do Kanaanu (14,20-23), a także bezbożni Izraelici w epoce przedmonarchicznej (Sdz 1-16) i monarchicznej (2 Krl 17-25). W opinii deuteronomistów spisujących dzieje swego narodu z perspektywy niewoli babiloń- 
skiej doczesne szczęście Izraelity jest w rękach Boga, a własna ziemia, dobrobyt i spokojne życie są Jego darem, który jest bezpośrednio i nieprzerwanie uzależniony od wiary i wierności JHWH.

$\mathrm{W}$ tej perspektywie teologicznej został ukazany również długi proces podboju i podziału Kanaanu przez Jozuego, a szczególnie jego teologiczne uwarunkowania, które odpowiadają na dwa zasadnicze pytania: kto może liczyć na dar ziemi od Boga (Joz 1-2) i kto ryzykuje jej definitywną utratę (2 Krl 17-25). W tym właśnie spektrum teologicznym pojawiają się najważniejsi bohaterowie księgi Jozuego: Jozue, syn Nuna, oraz Rachab. Ten pierwszy, dzięki swej wierze i bezgranicznemu posłuszeństwu, jest zaliczany do najjaśniejszych postaci starotestamentowych i jako sługa JHWH (Sdz 2,8) dopełnia zbawczej misji zapoczątkowanej przez Mojżesza, a jednocześnie wyznacza okres idealnie funkcjonującej teokracji w Izraelu. Nie ma w Biblii okresu, który mógłby konkurować z teokratycznymi rządami Jozuego pod względem posłuszeństwa i solidarności hebrajskich pokoleń. Niewiele jest też epok w dziejach Izraela, w których Bóg tak mocno angażował swą zbawczą obecność, jak to uczynił w czasie podboju Kanaanu. Przykładna postawa wiary i posłuszeństwa Jozuego oraz idealna postawa ludu, która nie posiada równego sobie biblijnego odpowiednika (Joz 1,16-18), są podawane jako powód spełnienia wszystkich Bożych obietnic, jakie zostały zakomunikowane przez JHWH patriarchom (Joz 21,43-45).

$\mathrm{W}$ tym idealnym schemacie teologicznym poczesne miejsce odgrywa niespodziewanie Rachab. W myśl redaktora księgi, jest ona uosobieniem (symbolem) człowieka (wspólnoty), który spotyka się z nadzwyczajną łaskawością JHWH, zostaje trwale otoczony Jego opieką, a także zyskuje status wolnego obywatela posiadającego własną ziemię i związanego więzami przymierza z Bogiem i Jego ludem. Tego rodzaju klucz hermeneutyczny jest dowodem niezwykłej odwagi i otwarcia deuteronomistycznego środowiska teologów na świat pogan i wymaga dokładnej analizy egzegetycznej. Lektorowi Biblii rodzi się bowiem spontanicznie pytanie dlaczego redaktor, znany ze swego przywiązania do tradycji, w kluczowym fragmencie księgi aż tyle miejsca poświęca cudzoziemce Rachab. Co więcej, dlaczego jej postawę ukazuje jako wzorzec dla każdego Izraelity, który pragnie być obdarowany ziemią i błogosławieństwem przez Boga. Rozmiary niniejszego przedłożenia nie pozwalają na gruntowne badania literackie i egzegetyczne passusu Joz 2,1-24. Należałoby to uczynić w oparciu o diachroniczne podejście do tekstu wymownie pokazujące jak ten kluczowy dziś fragment księgi stopniowo rozrastał się i ulegał kolejnym teologicznym modyfikacjom ${ }^{1}$, dzięki którym $\mathrm{z}$ oryginalnego opowiadania o anoni-

1 Szczegółową analizę procesu redakcji opowieści o wywiadowcach Jozuego i ich przymierzu z Rachab (2,1-24) podejmują wszystkie istotne monografie i komentarze do 
mowej kobiecie pomagającej izraelskim wywiadowcom w rozeznaniu sytuacji militarnej Jerycha stał się programowym tekstem teologicznym komunikującym prawdę o uniwersalizmie monoteizmu jahwistycznego, o zasadności teologii przymierza i starotestamentowej zasady Bożej odpłaty oraz o duchowej drodze pogan do Boga JHWH.

Z uwagi na literackie i redakcyjne bogactwo passusu Joz 2,1-24, w tak skondensowanej analizie z konieczności trzeba ograniczyć się jedynie do teologicznej syntezy zbudowanej na synchronicznym podejściu do tekstu biblijnego. Naszą uwagę skoncentrujemy więc na modelu wiary proponowanym Izraelitom przez redaktora deuteronomistycznego w oparciu o figurę Rachab ukazaną w kontekście upadku społeczno-politycznej struktury Kanaanu. Na bazie gruntownej teologicznej oceny tej postaci można wyprowadzić kilka kluczowych atrybutów postawy wiary, które deuteronomista przypisuje tej bohaterskiej cudzoziemce. Dzięki wierze Rachab w kontekście toczącej się wojny JHWH nie tylko ratuje własne życie i życie swych bliskich, ale też zyskuje wolność, nowy jasno zdefiniowany status społeczny i religijny oraz gwarancję materialnej niezależności. Oto kluczowe aspekty wiary biblijnej Rachab zarysowane w kluczowym passusie księgi Jozuego (2,1-24).

\section{1. Żywa wiara w zbawczą obecność JHWH w dziejach narodów i Jego więź z Izraelem}

Zanim zatrzymamy się na najważniejszym rysie postawy Rachab podkreślanym przez deuteronomistę $\mathrm{w}$ relacji $\mathrm{z}$ jej spotkania $\mathrm{z}$ wywiadowcami Jozuego, należy sprecyzować tożsamość głównej bohaterki oraz kontekst, w którym zostaje zaprezentowana przez edytora księgi. Otóż Rachab pojawia się w relacji inicjującej militarny podbój Kanaanu, który Jozue z woli JHWH postanawia rozpocząć od zdobycia starożytnego miasta Jerycha stanowiącego bramę do tej części Palestyny. Chcąc strategicznie przygotować się do tej operacji wojennej,

księgi Jozuego: M. H. Woudstra, The Book of Joshua (NICOT; Grand Rapids 1981) 67-76; R. Boling, G. Wright, Joshua: A New Translation with Notes and Commentary (AB 6; New Haven 2008) 139-152; T. Butler, Joshua (WBC 7; Dallas 1998) 24-35; D. Howard, Joshua (NAC 5; Nashville 1998) 96-117; C. Keil, F. Delitzsch, Commentary on the Old Testament. Joshua (Peabody 1996) 25-29; R. Hubbard, Joshua (NIVAC; Grand Rapids 2009) 109-133; J. Floss, Kunden oder Kundschafter? Literaturwissenschaftliche Untersuchung zu Jos 2. I. Text, Schichtung, Überlieferung (ATSAT 16; St. Ottilien 1982); Tenże, Kunden oder Kundschafter? Literaturwissenschaftliche Untersuchung zu Jos 2. II. Komposition, Redaktion, Intention (ATSAT 26; St. Ottilien 1986); E. Noort, Das Buch Josua: Forschungsgeschichte und Problemfelder (Darmstadt 1998). 
syn Nuna potajemnie posyła z obozu w Szittim dwu zwiadowców (Joz 2,1), aby zorientowali się w kwestii topografii terenu, struktury miasta i jego umocnień oraz zaczerpnęli opinii na temat nastrojów, jakie panują wśród mieszkańców Jerycha. Realizując rozkaz dowódcy, zwiadowcy nie chcą narażać się na zbędne niebezpieczeństwo, dlatego nie idą do centrum miasta, lecz wybierają przylegający do muru miejskiego dom, który okazuje się być własnością nierządni$\mathrm{cy}^{2}$, i tam postanawiają spędzić noc. Narrator od samego początku swej relacji nie koncentruje uwagi lektora na posłańcach Jozuego, lecz na postaci Rachab. Dowodem tego jest ich zupełna anonimowość i brak jakiejkolwiek informacji na temat ich wojskowego zwiadu w Jerycho i jego okolicach, który w zasadzie ogranicza się do swego rodzaju wywiadu środowiskowego uczynionego z Rachab, przy jednoczesnym nieproporcjonalnie szczegółowym opisie osoby, statusu społecznego, słów i czynów tej kananejskiej kobiety. W wyjątkowy dla księgi sposób, redaktor podaje nie tylko imię Kananejki, ale też wspomina o jej niechlubnej profesji oraz dokładnie precyzuje jej postawę wobec wywiadowców, która wpływa na dalszy bieg zdarzeń i pewnym sensie wyznacza ogólną teologiczną wymowę tego fragmentu księgi. Hebrajski termin zônâh oznacza w Biblii «nierządnicę, kobietę cudzołożną». Oczywiście w podstawowym swym sensie termin ten oznacza prostytucję jako naganny moralnie czyn lubieżny zorientowany na uzyskanie materialnej korzyści, choć w teologii deuteronomistycznej, kapłańskiej i prorockiej prostytucją określany jest także kult kananejskich bogów, którego Izraelici dopuszczali się w epoce przedmonarchicznej oraz monarchicznej (Wj 34,15-16; Kpł 17,7; 19,29; 20,5-6; Pwt 31,16; Jr 2,20.23-24; 3,3; 5,7; Ez 16,30-35) ${ }^{3}$. W perykopie 2,1-24 chodzi jednak

2 W swym opowiadaniu narrator nie zatrzymuje się na motywacjach zwiadowców i nie podaje kryterium, jakim kierowali się w wyborze miejsca na nocleg. Nie mówi też nic o tym, czy świadomie, czy też nieświadomie znaleźli się w domu nierządnicy. Trzeba jednak zauważyć, że wątek nierządu należy do istotnych motywów tej biblijnej relacji, tak na płaszczyźnie społecznej (nierząd jest tu pojmowany jako profesja kogoś, kto znajduje się na marginesie społeczności i jest zmuszony do tego typu procederu) i teologicznej (nierząd kultyczny - rozumiany jako cześć oddawana bogom kananejskim w kontraście do czci wobec JHWH).

3 W swej ostatecznej teologicznej perspektywie perykopa chce zwrócić uwagę lektora nie tylko na społeczny status Rachab, ale także na jej sytuację religijną, która z uwagi na to, że opiera się na kulcie bogów kananejskich może być porównana do prostytucji w stosunku do czystego kultu Boga JHWH. Niektórzy egzegeci, którzy usiłują podnieść moralny status Rachab, hebrajski termin $z \hat{n}$ âh wiążą z aramejskim $z \hat{u} n$ «karmić» i widzą w niej «oberżystkę dającą schronienie i pokarm podróżnym». R. Jamieson, A. Fausset, D. Brown, Commentary Critical and Explanatory on the Whole Bible (Oak Harbor 1997) (Joz 2,1-7). Ta opcja, choć zauważalna już we wczesnych komentarzach żydowskich i tekstach Józefa Flawiusza (Starożytności żydowskie, V, 8.1.2), nie jest w żadnym razie wnioskiem, jaki wypływa z tek- 
w pierwszym rzędzie o to pierwsze znaczenie, w związku z czym rodzi się od razu pytanie o postawę zwiadowców, której zasadność na pierwszy rzut oka budzi poważne zastrzeżenia. Udając się do kananejskiej nierządnicy, łamią surowy zakaz kontaktu z pogankami (Lb 25,1-18). Ponadto wydają się lekceważyć rozkaz Jozuego, gdyż, zamiast obserwować umocnienia Jerycha i zasięgać informacji na temat ruchów wojsk kananejskich, idą do nierządnicy. Poprzez misternie ukryte $\mathrm{w}$ tekście informacje narrator komunikuje lektorowi prawdziwe zamiary zwiadowców oraz sens całego epizodu. Czystość intencji Izraelitów dokumentuje wyrażeniem wajjābō'û bêt-'iššâh zônâh «weszli do domu nierządnicy» oraz wajjiš $k k^{e} b$ û šāmmâ «i zatrzymali się tam na spoczynek» $(2,1)$. W dalszej części narracji podaje dodatkowo informację, że dom Rachab znajdował się właściwie w murze miasta, gdyż bezpośrednio do niego przylegał $(2,15)$, czym ostatecznie wyjaśnia zamiary zwiadowców, którzy u Rachab nie szukali uciech cielesnych, lecz bezpiecznego schronienia i odpowiednich warunków pozwalających skutecznie wykonać dany sobie rozkaz 4 .

Na określeniu profesji Kananejki nie kończy się prezentacja kobiety oferującej gościnę Izraelitom. Narrator podaje również jej imię. O wyjątkowości tej informacji świadczy fakt, iż, poza zaledwie kilkoma wyjątkami ${ }^{5}$, księga Jozuego mówi prawie wyłącznie o bohaterach zbiorowych. Termin rāḥab_ ma pochodzenie semickie i oznacza «czynić szerokim, obszernym, przestronnym». Na starożytnym Bliskim Wschodzie rdzeń ten występował często w kontekście religijnym $\mathrm{w}$ odniesieniu do płodności kobiet, którą wiązano ściśle $\mathrm{z}$ boską łaskawością (np. e-lu-ra-hēe-ba «El otworzył łono»). Niektórzy egzegeci widzą w tym źródłosłowie zamierzoną ironię narratora, który pragnie z deprecjacją

stu natchnionego. Zresztą profesję nierządnicy przypisują Rachab bezpośrednio również tradycje nowotestamentowe (Hbr 11,31; Jk 2,25).

4 Dom Rachab jako miejsce bezpiecznego schronienia i gwarancja ocalenia funkcjonuje jako motyw przewodni w całej narracji. W 2,1 służy jako schronienie dla zwiadowców, natomiast w 2,18-19; 6,22-25 jest rękojmią ocalenia dla Rachab i jej całej rodziny. Taką interpretację potwierdza również złożony sens aktywności Kananejki, która, jak sugeruje jej imię oraz kontekst narracji, była nie tylko nierządnicą, ale też prowadziła dom dla podróżnych, w którym przygodni wędrowcy mogli znaleźć strawę oraz nocleg. Tego rodzaju miejsce było odpowiednim schronieniem dla posłańców Jozuego, gdyż mogli tam przebywać niezauważeni, a równocześnie zdobyć potrzebne im informacje strategiczne od przybywających tam gości.

5 Bohaterowie indywidualni nazwani z imienia, oczywiście poza kazusem Jozuego, który jest głównym protagonistą księgi, pojawiają się tylko w kilku przełomowych momentach narracji: Rachab jest wzorcem wiary i odwagi w 2,1-24, 6,22-25, Akan przykładem niewierności i nieposłuszeństwa (7,16-26), zaś Kaleb modelem wiernej służby nagrodzonej przez Boga (14,6-15). 
podkreślić wstydliwy zawód Kananejki ${ }^{6}$. Według innych jest wręcz odwrotnie: autor biblijny chce tym imieniem zaznaczyć jej gościnność, wiążąc imię Rachab z hebrajskim rêhōb «otwarty zaułek, plac publiczny» ${ }^{7}$. Jedno jest pewne. Choć imię Rachab nie przybiera w obrębie narracji sensu etiologii, to jednak istotnie i symbolicznie ilustruje status Kananejki oraz jej wyjątkową postawę w biegu opisywanych zdarzeń. Z jednej strony nawiązuje do jej kontrowersyjnej profesji, z drugiej akcentuje życzliwość i gościnność, a co najważniejsze, zapowiada jej otwarcie na Boga, które zaowocuje pięknym wyznaniem wiary, przymierzem z Izraelitami, a w konsekwencji przyniesie ocalenie jej samej i jej bliskim. Dokładna prezentacja Rachab jest świadomym zamierzeniem narratora. $\mathrm{Na}$ tle anonimowych zwiadowców Jozuego kananejska nierządnica od samego początku staje się główną bohaterką narracji dzięki swej wyjątkowej profesji, pochodzeniu, wymownemu imieniu, a jak pokaże dalsza część relacji, dzięki niezwykłej determinacji, odwadze, a przede wszystkim prostej, silnej i niezachwianej wierze w Boga JHWH.

Bo to właśnie wiara Rachab decyduje o wadze tej postaci w kontekście biblijnej relacji o podboju Jerycha i przejęciu przez Izraelitów ziem kananejskich. Deuteronomistyczny redaktor księgi w tej obcej kobiecie widzi teologiczny paradygmat, wzorzec człowieka, który zasługuje na Bożą łaskawość i wybawienie. O jej dojrzałej i głębokiej wierze w JHWH i Jego zbawczą obecność w historii Izraela, okolicznych narodów i całego wszechświata, zwiadowcy Jozuego dowiadują się z jej własnych ust zaraz po tym, jak uratowała ich życie, kierując pościg królewski poza bramy miasta. Jej monolog ma formę zwięzłego wyznania wiary, które zostało wkomponowane w oryginalną wersję opowiadania na jednym z ostatnich etapów redakcji księgi ${ }^{8}$. Do takiego wniosku dojść można na podstawie analizy diachronicznej tekstu. Opowiadanie o pobycie posłańców Jozuego u nierządnicy w Jerycho $\mathrm{w}$ pierwotnej wersji zaraz po redakcyjnym wstępie 2,8-9a zawierało prawdopodobnie jej wezwanie do wdzięczności, którą miała być odpłata za ocalenie ich z ręki żołnierzy króla (2,12-13). Hebrajska formuła $w^{e e}$ attâ «a teraz, a zatem», która rozpoczyna wiersz 2,12, a także jego treść, która komunikuje słowa Rachab domagające się rekompensaty za

6 R. D. Nelson, Joshua (Louisville 1997) 42.

7 J. Strong, Enhanced Strong's Lexicon (Bellingham 2001) 840; J. Swanson, A Dictionary of Biblical Languages with Semantic Domains. Hebrew (Old Testament) (Oak Harbor 2001) 8147 .

8 Na późne pochodzenie tego fragmentu narracji wskazuje większość komentatorów: D. Dorsey, The Literary Structure of the Old Testament: A Commentary on Genesis-Malachi (Grand Rapids 2004) 91; R. Hubbard, Joshua, 119-121; C. Keil, F. Delitzsch, Commentary, 27-28; T. Butler, Joshua, 27-32; F. Langlamet, «Josué II et les traditions de l'Hexateuque», $R B 78$ (1971) 5-17.161-183.321-354. 
jej odwagę i poświęcenie, wcale nie wynika z treści wyznania wiary Kananejki w JHWH (2,9b-11), lecz bezpośrednio nawiązuje do passusu 2,3-8. Ten właśnie passus podaje przyczynę, dla której zwiadowcy winni bez wahania okazać Rachab swą wdzięczność i złożyć wymaganą przez nią przysięgę. Zresztą, do wątku wyjątkowej konfesji Rachab, która nie znajduje odpowiednika w całej księdze Jozuego, nie odnosi się dalsza część relacji. W 2,14-21 zwiadowcy odwołują się do przysięgi, którą wymogła na nich Rachab w 2,12-13, natomiast nie wspominają ani słowem o jej wierze w Boga JHWH. Podobnie ma się rzecz w epilogu epizodu (6,22-25), w którym zostaje zrelacjonowane ocalenie całej rodziny Rachab, ale nie ze względu na wyznaną przez nią wiarę w Boga JHWH, lecz na przysięgę, którą złożyli jej posłańcy Jozuego. Jednym słowem oryginalna perykopa o spotkaniu Rachab ze zwiadowcami nie posiadała wierszy 2,9b-11 dokumentujących wyznanie wiary Kananejki, wiersze te zostały dodane dopiero przez redaktora księgi, który potraktował sekcję Joz 1-2 jako teologiczne wprowadzenie do całego dzieła. Dzięki wprowadzonym przez niego tradycjom dwa pierwsze rozdziały otwierające księgę ${ }^{9}$ prezentują lektorowi dwie wyraźnie określone postacie: Jozuego i Rachab, które będą wyznaczać teologiczny kontekst relacjonowanego w następstwie podboju Kanaanu. Poprzez te dwie figury narrator wyrazi własną, na wskroś teologiczną rekonstrukcję walk Izraelitów o ziemie palestyńskie, ale też określi kryteria, jakimi będzie się kierował JHWH i Jego wódz Jozue w przydziale zdobytej ziemi. W passusie 2,9b-11 ta teologiczna konwencja podboju Palestyny zostaje świadomie włożona w usta Kananejki Rachab po to, by służyć lektorowi jako światło pomagające właściwie odczytać teologiczny sens zdarzeń opisywanych w kolejnych odsłonach księgi.

Otwarcie mowy Rachab jest bardzo mocne i stanowcze. Formuła jād $a^{\prime} e t t \hat{\imath}$ «wiem» świadczy o silnym przeświadczeniu Kananejki co do prawdziwości i wiarygodności opisywanej przez nią rzeczywistości, a w obrębie opowiadania pozostaje $\mathrm{w}$ ewidentnym kontraście do dwukrotnie użytego wyrażenia $l \bar{o}^{\prime} j \bar{a} d \underline{a}{ }^{\prime} e t t \hat{\imath}$ «nie wiem, nie wiedziałam» $(2,4 \mathrm{~b}-5)$. Kananejka w spotkaniu ze strażnikami królewskimi, świadomie tając prawdę, podkreśla swą niewiedzę na temat pochodzenia i misji goszczących u niej mężczyzn oraz miejsca ich aktualnego pobytu i dalszych planów. W zupełnie innym tonie zabiera głos na te same kwestie w późniejszym dialogu ze zwiadowcami Jozuego (2,9b-11). Dzieli się z nimi nie zasłyszanymi przypadkiem pogłoskami i opiniami, ale

9 Dopełnieniem tej teologicznej struktury jest epilog księgi (21,43-45) podkreślający religijny aspekt opisywanych w niej zdarzeń, bezpośrednie zaangażowanie zbawcze JHWH oraz motyw wypełniających się Bożych obietnic. Uzupełnieniem tego strukturalnego schematu księgi jest też dodany później apendyks (22-24), który ujmuje proces podboju Palestyny w perspektywie teologii przymierza. 
gruntowną i sprawdzoną wiedzą ${ }^{10}$ na temat ich pochodzenia i zamiarów. Rachab, podobnie zresztą jak pozostali mieszkańcy Jerycha, których w spotkaniu ze zwiadowcami jest reprezentantką ( 1 os. $1 . \mathrm{mn}$. w 2,9b-11), zna doskonale tożsamość swych gości. Wie, że są Izraelitami, zna też fakty z ich niedalekiej przeszłości, a nawet przyszłości. I tak Rachab wie o nadzwyczajnym znaku osuszenia przejścia przez Morze Sitowia, jakie miało miejsce w końcowym etapie wyjścia Izraelitów z niewoli egipskiej kładąc kres ich prześladowaniu $(2,10)$, wie o zwycięstwie nad armią amoryckich królów: Sichona i Oga (2,10b; por. Lb 21,21-32.33-35; Pwt 2,26-28; 3,4-5). A co najważniejsze, wie o specjalnej relacji przymierza, jaka łączy naród izraelski z Bogiem JHWH (2,11a). Kananejska niewiasta wie również, że JHWH, Bóg Izraela, jest Panem całego wszechświata i wszystkich narodów. Tak bowiem należy rozumieć formułę, która w opisowy sposób wyraża Boże imię «JHWH, Bóg wasz, jest Bogiem wysoko na niebie i nisko na ziemi» $(2,11 b)^{11}$. Formuła ta jest kwintesencją jej religijnej konwersji. Żyjąc w świecie politeistycznym, Kananejka odchodzi od religijnej tradycji swego narodu i w JHWH, Bogu Izraela, dostrzega Pana i Boga całego wszechświata i wszystkich ludzi. W JHWH widzi prawdziwego Boga i Władcę, przed którym drżą i padają wszystkie największe cywilizacje i władze jej epoki, a także ich bogowie. W JHWH upatruje siły izraelskiego narodu, w Nim wyznaje gwarant zwycięstwa w mającej nadejść wojnie o Palestynę. Wiara Rachab jest porównywalna z wiarą Jozuego (Lb 14,6-9; Pwt 31,1-8) oraz z modelem wiary reprezentowanym przez deuteronomistycznego redaktora opisanym $\mathrm{w}$ prologu księgi (Joz 1,1-18; por. Pwt 2,24-36). W zaprezentowanej w mowie Rachab konwencji teologicznej wiara $\mathrm{w}$ JHWH polega na przekonaniu, że wypełnia On dane przez siebie obietnice, że Jego wszechmocy, której podporządkowane

10 Można pytać o źródło tej wiedzy. Teologiczny kontekst perykopy sugeruje, że jej źródłem jest Boże objawienie. W tej właśnie perspektywie figurę nawróconej na monoteizm jahwistyczny Rachab interpretuje wielu żydowskich komentatorów.

11 Formuła baššāmajim mimma'al we 'al-hā'āreș mitāhat «w niebie wysoko i na ziemi nisko» (por. Wj 20,4; Pwt 4,39; 5,8; $1 \mathrm{Krl} 8$,23) jest rodzajem figury retorycznej (meryzm wskazujący dwa skrajne punkty konkretnej rzeczywistości, by wyrazić jej całość lub komplementarność, por. Rdz 1,1). W kontekście mowy Rachab dwa ekstrema kosmosu, którymi są šāmajim «niebo» i 'ereș «ziemia», podkreślają niepodważalną wszechmoc Jahwe i Jego władzę nad wszechświatem i tym, co go napełnia. Niektórzy w wyznaniu Rachab dopatrują się monoteizmu jahwistycznego $\mathrm{w}$ jego czystej postaci, to znaczy przekonania promującego JHWH jako jedynego istniejącego Boga w świecie (por. 1Krl 8,60; Iz 45,14-21; Dn 3,96). Rachab z pewnością uznaje wyższość Jahwe nad bogami Kanaanu: Baalem i Asztarte, a także bogami tych okolicznych ludów, które uległy militarnie wędrującym Izraelitom, jednakże w jej wypowiedzi nie ma jasno sformułowanej tezy o JHWH jako jedynym Bogu wszechświata. W epoce przedmonarchicznej Izraelici czcili JHWH, ale nie wykluczali istnienia innych bóstw (Joz 24,15-18). 
są nawet siły natury, nie może stawić czoła żadna potęga ludzka, i że napełnia On wielkim lękiem swych wrogów, natomiast łaskami i życzliwością swoich wiernych czcicieli. Największym dobrodziejstwem, jakim Pan obdarza swych wyznawców w epoce Jozuego i Rachab, jest osobista wolność oraz podniesienie społecznego i materialnego statusu, którego symbolem jest własna ziemia. Z tego tytułu drżą przed JHWH wszyscy mieszkańcy Jerycha i całego Kanaanu dopuszczający się wyzysku i nieprawości ${ }^{12}$, natomiast cieszą się uciśnieni, zepchnięci na margines i pogardzani wskutek niesprawiedliwych relacji społecznych. Reprezentantem tej właśnie klasy społecznej jest Rachab, która w przybyciu Izraelitów dostrzega zapowiedź oczekiwanych przez nią zmian. Kananejka nie tylko zna imię Boga Izraelitów - JHWH, ale też przyzywa Go wielokrotnie w rozmowie ze zwiadowcami (2,9-11.12-14). Jemu przypisuje wielkie znaki dokonane w Egipcie i na pustyni oraz skuteczność działań militarnych podejmowanych przez Jozuego. Potęga JHWH jest według niej powodem wielkiego strachu mieszkańców Jerycha i Palestyny ${ }^{13}$ oraz bezpośrednią przyczyną upadku całej kananejskiej cywilizacji, która musi odejść w cień na rzecz społeczności hebrajskich pokoleń. Warto zauważyć, że do takiego wniosku na tym etapie narracji dochodzi tylko ta kananejska kobieta, natomiast milczą w tej kwestii Jozue i Izraelici. Trzeba pamiętać, że w starożytności klęska w wojnie oznaczała jednoczesny upadek społecznych, kulturowych i religijnych struktur pokonanego narodu. Wraz z pobitym narodem wojnę przegrywał również czczony przez niego bóg (bogowie), i odwrotnie, zdobytą ziemię brał w posiadanie nie tylko zwycięski naród, ale też wyznawany przez niego bóg (bogowie). Mówiąc o zwycięskim marszu Boga Izraela - JHWH, Rachab zapowiada właśnie tego rodzaju sytuację. Dlatego też w rozmowie $\mathrm{z}$ hebrajskimi zwiadowcami wyznaje zdecydowaną wiarę w Boga Izraelitów, rozpoznaje w Nim prawdziwego Pana i Władcę wszechświata, a co najważniejsze, chce przejść na Jego stronę, gdyż

12 Mówiąc o trwodze i lęku, jaki zagościł w sercach i umysłach jej rodaków na wieść o zbliżającej się armii Jozuego oraz kroczącym na jej czele JHWH, Rachab odnosi się nie tylko do swych współziomków z Jerycha, ale też do wszystkich Kananejczyków (por. znaczenie hebr. wyrażenie kāl-jōšebê hā' āreș «wszyscy mieszkańcy ziemi»).

13 Hebrajski czasownik māsas «rozkładać się, topnieć» z rzeczownikiem lēbāa $\underline{b}$ «serce» tworzą idiomatyczne wyrażenie oznaczające «głęboki i paniczny strach powodujący gwałtowną reakcję emocjonalną wywołującą omdlenie lub utratę kontroli nad własnym ciałem, jaźnią». Polskie idiomy określające tak silną reakcję emocjonalną to m.in. «mdleć ze strachu», «być sparaliżowanym ze strachu». Paniczny lęk przed JHWH u przedstawicieli obcych ludów w kontekście wojny jest motywem typowym dla literatury deuteronomistycznej (Pwt 1,28; 20,8; Joz 5,1; 14,8; 2Sm 17,10). M. Weinfeld, Deuteronomy and the Deuteronomic School (Oxford 1972) 344. 
liczy na Jego łaskawość i przychylność, a także spodziewa się życzliwości wybranego przez Niego narodu.

W księdze Jozuego wszystko jest więc ujęte w konwencji wojny JHWH, która toczy się pod dyktando wszechmogącego Boga walczącego w imieniu Izraela i kończy się druzgoczącą klęską Kananejczyków oraz zdobyciem i podziałem ziemi przez hebrajskie pokolenia. Motywem bezpośredniego zbawczego zaangażowania się JHWH w dzieje Izraela jest Jego pragnienie wypełnienia obietnic danych w przeszłości patriarchom i zagwarantowanie członkom narodu wybranego własnej ziemi w Palestynie, do której jako pierwszy został posłany przez Niego Abram (Rdz 12). Ta wojna nie ma charakteru inwazji zbrojnej, wojny zaborczej, jest pokazana jako walka wyzwoleńcza, którą mocą swego Boga prowadzi uciemiężony i zniewolony przez wieki lud dążący do położenia kresu długotrwałemu wyzyskowi i niesprawiedliwości społecznej. Z tego względu redaktor księgi nie skupia się na militarnym czy strategicznym aspekcie opisywanych zdarzeń, lecz na ich wymiarze teologicznym. To nie Izraelici zwyciężają Kananejczyków i zdobywają sobie ziemię. Czyni to JHWH, przed którym drżą ze strachu władcy i obywatele Palestyny, nie dotrzymując kroku w konfrontacji zbrojnej z wojskiem Jozuego. To Bóg daje ziemię swemu narodowi wybranemu, Rachab wierzy w to głęboko, co więcej jest pewna, że tak się stanie. Jej żywa i silna wiara w realną i zbawczą obecność JHWH w historii Izraela oraz wchodzących z nim w konflikt narodów nie jest tylko kwestią emocji, pragnień czy wewnętrznych osobistych przemyśleń, lecz bazuje na wnikliwej i rzeczowej obserwacji dokonującej się wokół niej rzeczywistości. Ostatecznym owocem tego procesu jest jej religijna apostazja. Rachab porzuca kananejską tradycję i religię ojców na rzecz kultu obcego dotąd Boga JHWH, który ujął ją swą wszechmocą, pociągnął bliską relacją z wybranym przez siebie narodem oraz przekonał do siebie obietnicami ziemi i wolności dla każdego uciśnionego, który stanie się Jego wyznawcą. Rachab zrozumiała, że, w przeciwieństwie do lokalnych bóstw Palestyny, Bóg Izraela jest Bogiem żywym, który potrafi okazać niezwyciężoną moc w konfrontacji z wrogami, ale też swe miłosierdzie i życzliwość wobec tych, którzy cierpią niesprawiedliwe prześladowanie i są wyzyskiwani przez silniejszych. W postawie Rachab można z pewnością dostrzec znaczący pragmatyzm. Kananejka widzi w nadchodzącym ludzie zwycięzców, którzy w powszechnej opinii ówczesnych mieszkańców Kanaanu mieli zupełnie zmienić socjalną i geopolityczną sytuację tego regionu, dlatego świadomie pragnie stać się jego sojusznikiem, by cieszyć się jego przychylnością. Redaktor księgi kładzie jednak znacznie większy nacisk na teologiczny aspekt religijnej metamorfozy Rachab. Zgodnie z ówczesną mentalnością i religijnością, Rachab zauważa i akceptuje decydującą rolę Boga Izraelitów, który w jej oczach był ostateczną przyczyną militarnego sukcesu Hebrajczyków. Przywołując wszystkie najważ- 
niejsze epizody zbawcze z epoki wyjścia Izraelitów z Egiptu i wędrówki przez pustynię, Kananejka manifestuje swój podziw i uwielbienie wobec mocy i łaski Bożej kryjącej się za tymi zdarzeniami. I to właśnie dzięki tej głębokiej i trafnej ocenie historii Izraela, a także decydującej w niej roli JHWH rozumianego jako Boga i Pana całej ludzkości, służy jako wzorzec wiary dla wszystkich Izraelitów i nie-Izraelitów ${ }^{14}$.

\section{Społeczne i materialne ubóstwo wołające o sprawiedliwą Bożą odpłatę}

Drugą istotną cechą biblijnej Rachab jest jej ubóstwo oraz bardzo niska pozycja społeczna. Jak podkreślone zostało wyżej, Kananejka jest określona terminem zônâh, który w Biblii oznacza «nierządnicę, kobietę cudzołożną», jednakże deuteronomistyczny redaktor księgi Jozuego ani jednym słowem nie ocenia moralnego czy religijnego aspektu jej postępowania. Na pierwszy rzut oka można byłoby to tłumaczyć faktem przynależności narodowościowej Rachab, która była Kananejką, a nie Izraelitką związaną nakazami prawa Bożego i przymierza zakazującymi takiego procederu (Wj 20,14.17). Z teologicznego kontekstu księgi widać jednak wyraźnie, że deuteronomistyczny redaktor pragnie zwrócić uwagę lektora zarówno na pochodzenie, jak i na profesję Rachab, która nie jest przypadkowa ani w bliskim, ani w dalszym kontekście relacji. Prostytucja w kulturach starożytnego Bliskiego Wschodu była traktowana jako pewnego rodzaju zjawisko społeczne. W konkretnych uwarunkowaniach społecznych nierząd był po prostu interpretowany jako skuteczny sposób zarabiania na życie i jako taki nie był przedmiotem ani religijnych zakazów, ani nie był ścigany przez obowiązujące prawo świeckie, co widać również na przykładzie relacji Judy i Tamar w Rdz 38. Biblia Starego Testamentu nie mówi często o nierządnicach, z imienia wymienia jedynie trzy kobiety trudniące się tym zajęciem: wspomnianą wyżej Tamar, omawianą przez nas Rachab oraz Filistynkę Dalilę - konkubinę sędziego Samsona (Sdz 16,1-21). Opisując te trzy figury kobiece, tekst biblijny ani razu nie ocenia moralnej strony ich postępowania, natomiast skupia się na intencjach oraz społecznym kontekście, w którym żyły. Istotą problemu jest w Biblii to, czy swą profesję wykonywały dobrowolnie, dla dużego i szybkiego zysku, czy też były do niej bezpośrednio lub pośrednio przymuszone poprzez trudną sytuację materialną. I tak Dalila jest pokazana

14 Pokrewne pod względem treści i formy wyznanie wiary prezentują inne teksty deuteronomistycznej historii Izraela wielbiące JHWH jako najwyższego (jedynego) Pana i Boga Izraela oraz całego wszechświata (Pwt 4,35-39; 7,9-10; 10,14-17; 1Krl 8,23.60). 
jako bezwzględna, cyniczna i wyrachowana poganka, która bez skrupułów wykorzystuje związek emocjonalny z Samsonem, aby zdobyć profit materialny obiecany jej przez współziomków ( $\mathrm{Sdz}$ 16,5-18). Tylko ta kobieta skupia w sobie wszystkie negatywne cechy, które nierządnicom przypisuje tekst natchniony (Prz 2,16-19; 5,1-5; 6,26; 9,13-18). Inaczej ma się rzecz z Tamar i Rachab. Obydwie znajdują się na skraju nędzy, a zatem nierząd jest dla nich jedyną skuteczną alternatywą, aby pozostać przy życiu. Tamar jest pozbawiona męża i nie posiada dzieci, nie ma też żadnych nadziei na poprawę swej sytuacji (prawo lewiratu) z uwagi na decyzję patriarchy Judy obawiającego się o życie swego syna Szeli (Rdz 38,8-14). W trudnym dla siebie położeniu Tamar popisuje się jednak wielką mądrością i sprytem, i tak zmienia swój status społeczny wdowy, nie tylko uzyskując bliźniacze potomstwo, ale też na trwałe wchodząc w dzieje pokolenia Judy i uniwersalną historię zbawienia ( $\mathrm{Rdz} 38,16-30$; Mt 1,3). Na podobny kontekst wskazuje również autor relacji o Rachab. I on nie ocenia moralnej postawy Kananejki, co więcej, zdaje się delikatnie podpowiadać jej sprawiedliwość. I choć nie mówi tego bezpośrednio, jak to często się zdarza w przypadku biblijnych autorów, którzy często zdają się na przenikliwość i mądrość lektorów, przez misternie ukryte w narracji informacje sugeruje pośrednio, że nierządnica Rachab została zobligowana przez materialny przymus do swej nagannej moralnie profesji. Pierwszym takim sygnałem jest jej otwarta i zdecydowana postawa wobec posłańców Jozuego, którym w żadnym momencie wizyty nie proponuje swych seksualnych usług w zamian za gratyfikację finansową lub jakieś inne korzyści ${ }^{15}$. Drugim mocnym argumentem jest jej obszerne wyznanie wiary w Boga JHWH i Jego zbawczą obecność w dziejach Izraela, które stanowi najważniejszy podtekst dla spotkania z wywiadowcami. Trzecim natomiast są jej mizerne warunki materialne, o których narrator opowiada w kontekście konieczności utrzymania i ocalenia całej rodziny.

Pierwsze dwa argumenty zostały omówione wyżej, oto krótka analiza ostatniego z nich. Materialne ubóstwo Rachab nie jest wyraźnie widocznym motywem narracji, lektor może je jednak z łatwością dostrzec, kiedy zatrzyma się na kilku detalach opowiadania. Pierwszym z nich jest położenie domo-

15 Niektórzy egzegeci sugerują tego rodzaju interpretację w oparciu o znaczenie hebrajskich terminów bồ "wejść» $(2,1)$, którego jedno z wielu znaczeń ma też podtekst seksualny (Rdz 6,4; 30,3; 38,8; 38,9; 39,14; Pwt 22,13; Sdz 15,1; 16:1), zônâh «nierządnica» oraz ša $\underline{a} a \underline{b}$ "położyć się, kłaść się». Również ten ostatni rdzeń w niektórych biblijnych tekstach jest eufemicznym określeniem zbliżenia seksualnego ( $\mathrm{Rdz} 19,33.35 ; 26,10 ; 30,15 ; 34,2 ; 35,22 ; \mathrm{Kpł}$ 15,24.33; Rt 3,4; 1Sm 2,22). D. Madvig, «Joshua», w: F. Gaebelein, The Expositor's Bible Commentary, t. 3: Deuteronomy, Joshua, Judges, Ruth, 1-2 Samuel (Grand Rapids 1992) 259-260. Gruntowna analiza Joz 2,1-24 w żadnym jednak razie nie daje racjonalnych powodów, by to znaczenie tego terminu aplikować do historii Rachab. 
stwa Rachab ${ }^{16} . \mathrm{Z}$ przebiegu narracji trudno jest wywnioskować jak wyglądał i z ilu składał się pomieszczeń dom Kananejki. Wiadomo tylko, że miał dolną kondygnację oraz dach, na którym można było się schronić $(2,6.8)$, a także to, że przylegał do murów miasta w taki sposób, że w praktyce był ich integralną częścią $(2,15)$. Biblia na żadnym miejscu nie oferuje informacji na temat ludzi mieszkających w murach miasta, a zatem trudno o jakieś precyzyjne wnioski w tej materii. Narrator wspomina o tej specyficznej lokalizacji domostwa Rachab w kontekście ucieczki zwiadowców Jozuego. Opowiadając o tym zdarzeniu, notuje, że Kananejka opuściła na sznurze obydwu mężczyzn z okna swego domu poza mury miasta. Było to możliwe, ponieważ stanowił część miejskich obwarowań. Biorąc jednak pod uwagę nieco szerszy teologiczny kontekst całego zdarzenia, można wnioskować, że tego rodzaju zamieszkanie nie było synonimem zamożności, lecz raczej surowej konieczności spowodowanej materialnym ubóstwem. Tak więc materialna bieda oraz upokarzająca przymusowa praca Rachab zdają się wzajemnie warunkować i w decydujący sposób wpływają na status społeczny oraz tryb życia tej kananejskiej niewiasty i jej najbliższych.

Drugim argumentem wskazującym pośrednio na ubóstwo Rachab jest znacząca liczebność rodziny, która, jak wynika z kontekstu relacji, pozostaje na jej stałym utrzymaniu, a przynajmniej Kananejka czuje się za wszystkich swych domowników odpowiedzialna. Na bazie opisu biblijnego trudno jest wnioskować, jaki był rodzinny i społeczny status tej kobiety. Wylicza ona swego ojca, matkę, braci i siostry $(2,13.18)^{17}$, natomiast nic nie wspomina o mężu i dzieciach. Biorąc pod uwagę kulturowy i religijny kontekst Biblii, czyli uwarunkowania życia Izraelitów i innych społeczności żyjących w Kanaanie w okresie patriarchalnym i przedmonarchicznym, można przypuszczać, że Rachab była bezdzietną wdową, bądź kobietą niezamężną z uwagi na materialne ubóstwo domu swego ojca. Tak czy inaczej, materialna bieda oraz konieczność utrzymania licznej rodziny wydają się być głównymi czynnikami, które zmusiły kobietę kananejską do wejścia na drogę prostytucji i nierządu. Narrator nie wyjaśnia dlaczego ojciec i bracia Rachab oraz pozostali męscy członkowie jej rodu nie byli w stanie zaspokoić materialnych potrzeb rodziny. Daje jednakże pośrednio do zrozumienia, że skutecznym sposobem na przetrwanie rodziny stał się

16 Niektórzy egzegeci o ubóstwie rodziny Rachab wnioskują na bazie obecności suszących się łodyg lnu na dachu jej domu $(2,6)$, które były uprawiane poza murami miasta i odpowiednio wysuszone stanowiły materiał na odzież dla najuboższych warstw społecznych.

17 Wiersz 2,18 wspomina jeszcze o innych członkach rodziny («cały dom twojego ojca»). Ci jednak mogli mieszkać poza domem Rachab, a pojawiają się tu jedynie w kontekście krewnych Kananejki, których ta chciała uratować od nadchodzącej zagłady miasta. 
nierząd jednej z córek - Rachab, która pracując dodatkowo jako oberżystka zdobywała środki umożliwiające przetrwanie swym najbliższym.

Powyższy opis stawia Rachab i jej bliskich w bardzo specyficznej perspektywie teologicznej, która w Biblii jest zarezerwowana dla tak zwanych «ubogich JHWH». Zepchnięci na margines społeczny przez niesprawiedliwość i wyzysk najeźdźców lub struktur władzy wspólnot, w obrębie których egzystowali, byli zmuszeni wieść życie pełne niedostatku i codziennych upokorzeń bez konkretnych i realnych nadziei na zmianę swej sytuacji. Teksty biblijne bardzo często aplikują tę kategorię teologiczną do prześladowanych w niewoli Izraelitów, których jedynym oparciem i gwarancją na polepszenie poziomu życia był Bóg JHWH. Bóg Izraela, pomny na przymierze zawarte ze narodem wybranym, nigdy nie pozostaje głuchy na wołanie uciśnionych i prześladowanych i zawsze przychodzi im z pomocą (Ps 9-10; 22; 25; 69; Jr 20,12-13). Szczególne miejsce w kategorii ubogich JHWH zajmowały sieroty, wdowy i cudzoziemcy. Te trzy grupy społeczne znajdowały się pod szczególną opieką JHWH i mogły zawsze liczyć na Jego życzliwość i wybawienie z uwagi na brak jakiejkolwiek pomocy ze strony innych ludzi. W tę specyficzną kategorię osób narrator wpisuje również Rachab, podkreślając, że jej stan materialny i głębokie upokorzenie domagały się interwencji zbawczej Boga. W tym przypadku na plan drugi schodzi jej przynależność etniczna. Dla łaskawości JHWH nie jest żadną przeszkodą w tym momencie jej kananejskie pochodzenie, ponieważ bieda i cierpienie rani i upokarza tak samo każdego człowieka, a wszyscy ludzie pozostają pod przemożnym panowaniem Boga sprawiedliwie rządzącego wysoko na niebie i nisko na ziemi $(2,11)$. Każdy więc człowiek i społeczność ludzka musi się liczyć z Bożą odpłatą, która wiązać się będzie zawsze ze sprawiedliwą karą dla prześladowców, natomiast $\mathrm{z}$ nagrodą wolności i dostatku dla niesłusznie wykorzystywanych, pogardzanych i prześladowanych (Iz 3,14-15; 32,6-7; Am 1-2; $4,1 ; 8,4)$. Warunkiem uzyskania Bożej pomocy jest stan cierpienia i negatywnych doświadczeń spowodowanych krytycznymi warunkami życiowymi, a jednocześnie ufność pokładana w Bogu i modlitwa zanoszona do Niego z prośbą o interwencję zbawczą (Ps 74,19; 149,4; Iz 49,13; 66,2; So 3,12-13). Rachab spełnia wszystkie te warunki, dlatego w księdze Jozuego jest pokazana jako ta, której trudna sytuacja życiowa zostanie radykalnie odmieniona dzięki Bogu JHWH działającemu rękoma Izraelitów. Teologiczny kontekst narracji sugeruje lektorowi, że wkrótce w miejsce upokorzenia, nędzy i niewoli, w życiu Rachab i jej bliskich zagoszczą wolność, dostatek, radość i pokój.

Perykopa 2,1-24, w sposób typowy dla starotestamentowej teologii pokazuje, że prawdziwa i silna wiara człowieka ma silne i głębokie zakorzenienie w jego codzienności. Świadkowie biblijnej wiary są zawsze życiowymi realistami. Zaufanie, które pokładają w Bogu daje im siłę i wytrwałość w przezwy- 
ciężaniu wszelkich prób i doświadczeń, daje im nadzieję, która nie pozwala się poddać nawet w bardzo trudnych okolicznościach. Co więcej, te trudności są dla nich często źródłem jeszcze większej wiary w Boga, który jest przez nich postrzegany jako jedyne źródło mocy i ukojenia, jako rękojmia nadziei na przyszłość oraz gwarancja sprawiedliwej odpłaty za znoszone długo cierpienia i upokorzenia. W przypadku biblijnej Rachab kwestia ta jest o tyle godna podkreślenia, że nie chodzi tu o członka ludu wybranego, lecz o kananejską neofitkę, która w swej społecznej i materialnej biedzie dostrzega w Bogu Izraela jedynego i prawdziwego obrońcę i wybawiciela prześladowanych, uciśnionych i ubogich, a w ufnej wierze JHWH rozwiązanie swych najboleśniejszych problemów życiowych. Rachab po prostu wierzy i ufa, że JHWH, który jest Bogiem wysoko na niebie i nisko na ziemi, który w przeszłości osuszył wody Morza Sitowia przed Izraelem, pokonał przed nim władców pustyni, a niedługo odda mu we władanie cały Kanaan (2,9-11), może przyjść z pomocą również jej i całemu jej domowi, kładąc kres niedoli i niesprawiedliwości, które stały się ich udziałem.

\section{Realizm, mądrość życiowa oraz niestrudzona walka o poprawę warunków bytowych}

Poza silną wiarą, biblijna Rachab cechuje się dużą odwagą, niezwykłym darem przenikliwej obserwacji otaczającej rzeczywistości oraz niezwykłą zdolnością adaptacji do zmieniającej się sytuacji społecznej i politycznej. Rachab jest pokazana jako głowa rodu, ale też jako wytrawny strateg, doświadczony i przebiegły negocjator, który z roztropnością i mądrością potrafi wykorzystać wszystkie nadarzające się okoliczności oraz użyć własnych zdolności i możliwości, aby ocalić życie swych bliskich. Kananejka jest modelem człowieka, który z jednej strony nigdy nie pogodził się z upokarzającym statusem społecznym i materialnym swej rodziny, a z drugiej czyni wszystko, aby tę niekorzystną sytuację odmienić. Desperację, a jednocześnie realizm życiowy Rachab widać w każdym wierszu deuteronomistycznego opowiadania o zwiadowcach w Jerycho. Pierwszym aktem jej mądrości i przewidywania było schronienie, jakiego użyczyła w swym domu dwom zwiadowcom Jozuego. Narrator nie relacjonuje bliżej okoliczności, w jakich Kananejka poznała, iż ma do czynienia ze szpiegami izraelskiego wojska, ton narracji sugeruje, że rozpoznała ich od razu $(2,1 \mathrm{~b}-6)$, od razu też dostrzegła, jak wielkie niebezpieczeństwo grozi im ze strony króla Jerycha, dlatego natychmiast zaoferowała swym gościom kryjówkę na dachu domu. W tym względzie okazała się o wiele przezorniejsza i doświadczona od samych wywiadowców, którzy byli pewni, iż do domu nierządnicy weszli nie- 
spostrzeżenie i będą tam mogli przebywać bezpiecznie. Tymczasem ich wejście do miasta od razu zostało zauważone i doszło do wiadomości władcy, ściągając na ich głowy śmiertelne niebezpieczeństwo $(2,2)$. Jeszcze tej samej nocy żołnierze króla stawili się u Rachab, wiedząc nie tylko o obecności Izraelitów w jej domu, ale też znając doskonale ich tożsamość oraz cel ich misji. Mądrość Rachab, która w tej konkretnej sytuacji ewidentnie góruje nad wojskowym doświadczeniem najlepszych zwiadowców Jozuego, sprawia, że Izraelici mogą ocalić życie. Jak dyskretnie, ale wymownie informuje narrator w 2,4a.6, Kananejka dokładnie ukryła swych gości zanim nadeszli posłańcy króla, a w rozmowie z nimi wykazała się dużą odwagą, determinacją i przebiegłością, inteligentnie okłamując ich co do dokonanych niedawno zdarzeń. Rachab nie zaprzeczyła, iż przybyli do niej obcy wędrowcy, ale zaraz potem serią kłamstw i dwuznacznych odpowiedzi zabarwionych dużym ładunkiem emocjonalnym skierowała uwagę ścigających na fałszywy trop. Podobnie jak przypadku zwiadowców Jozuego, kobieta natychmiast przejrzała intencje oraz możliwości wysłanników króla. Wykorzystując bezwzględnie i inteligentnie swoją specyficzną profesję oraz zakłopotanie przybyszów (znajdowali się w domu nierządnicy), Rachab z jednej strony pewnością siebie, a z drugiej udawaną szczerością, naiwnością i obojętnością na dokonujące się wokół niej zdarzenia, zdominowała dialog z żołnierzami króla i odesłała ich z poczuciem dobrze spełnionej misji. Udając mało pojętną kobietę, której jedynym zajęciem było dawanie schronienia i uciech cielesnych odwiedzającym ją gościom, skutecznie przekonała żołnierzy, że ktoś taki jak ona nie mógłby być zagrożeniem dla Jerycha i w żadnym razie nie mógłby świadomie udzielić pomocy czającemu się za murami nieprzyjacielowi ${ }^{18}$. Odegrana doskonale rola nierządnicy, której zupełnie nie inte-

18 Tekst narracji ukazuje sprytne działanie Rachab za pomocą dwukrotnego użycia formuły «nie wiem /nie wiedziałam/» $l \bar{o}^{\prime} j a \bar{a} \underline{d} a{ }^{\prime} t \hat{\imath}(2,4.5)$, która podkreśla udawaną przez przebiegłą Kananejkę niewiedzę zarówno w odniesieniu do pochodzenia i zamiarów jej nieznajomych gości, jak też co do ich dalszych planów oraz drogi, którą obrali po wyjściu z jej domu. Ironia narracyjna zawarta w opowiadaniu polega na tym, że prawda była zupełnie inna. W chwili, kiedy Rachab rozmawiała z posłańcami króla, na dachu jej domu przebywali ukryci przez nią zwiadowcy, z kolei w dalszej części opowiadania Kananejka wskaże im dokładnie kierunek ucieczki i pouczy o tym, jak długo mają się ukrywać, by nie wpaść w ręce swych prześladowców. Na podstawie 2,7 lektor dowiaduje się, że posłańcy królewscy kontynuowali pościg w kierunku brodów Jordanu (hebr. derek hajjaredēn 'al hamma 'eberôt «drogą wiodącą w stronę Jordanu, aż do brodów», to znaczy najkrótszą drogą, która prowadziła do obozu Jozuego. Najbliższej nocy Rachab kolejny raz zademonstrowała swą niebywałą mądrość i roztropność, kiedy, przewidując ruch żołnierzy, poradziła zwiadowcom, aby udali się w zupełnie inną stronę, to znaczy w góry, i tam pozostali przez trzy dni aż do czasu powrotu żołnierzy królewskich do miasta $(2,16)$. Dopiero po upływie tego terminu będą mogli bezpiecznie wrócić do swego mocodawcy tą sama drogą, którą trzy dni wcześniej 
resują kwestie militarne czy polityczne, lecz jedynie zdobywanie korzyści materialnych, poparta okazywanym wylewnie zrozumieniem dla misji posłańców królewskich i pragnieniem udzielenia im pomocy ${ }^{19}$ na tyle uspokoiła posłańców króla, że zrezygnowali z przeszukania domu Kananejki i odeszli śpiesznie, aby rzucić się w pogoń za uciekinierami. Żołnierze byli przekonani, że ktoś taki jak Rachab był zbyt mało inteligentny i odważny, aby udzielić pomocy obcemu zwiadowi, a nawet zorientować się, że ma przed sobą przedstawicieli obcego wojska. Co więcej, barwna wypowiedź nierządnicy tak ich urzekła, że dali wiarę nie tylko jej zapewnieniom, iż obcy mężczyźni już odeszli, ale też poszli, by szukać ich we wskazanym przez nią kierunku (2,4-5.7). Udając więc nic nie rozumiejącą nierządnicę a jednocześnie głośno manifestując pozorowaną lojalność wobec lokalnej władzy, Rachab oszukuje pewnych siebie wysłanników króla i ratuje wywiadowców Jozuego. W podsumowaniu tej części opowiadania $(2,7)$ narrator ukazuje skuteczność chytrego planu Rachab: królewscy posłańcy kontynuują pościg aż na peryferie, daleko od miasta, a w tym samym czasie zostają zamknięte na noc bramy Jerycha, co ostatecznie potwierdza bezpieczeństwo dwóch Izraelitów.

Nie przezorność i przebiegłość Rachab jest tu jednak najważniejsza. O wiele istotniejsze dla lektora tej narracji winno być pytanie: dlaczego Kananejka pomaga obcym szpiegom? Z jakiego powodu okłamuje i wywodzi w pole wysłanników króla? Przecież takim działaniem występuje przeciw swemu narodowi, wiedząc, że Izraelici przyniosą mu wojnę, śmierć i zniszczenie. Aby to zrozumieć, trzeba przypomnieć sobie naszkicowany wyżej materialny i społeczny status Kananejki w Jerycho oraz surowe uwarunkowania jej pełnego upokorzeń życia. W wizycie Izraelitów, przed którymi drżało całe miasto i okolice z uwagi na rozchodzącą się famę o ich militarnych sukcesach odniesionych nad okolicz-

podążyli wysłańcy królewscy. Jak notuje narrator w 2,22, wywiadowcy Jozuego posłuchali rad Rachab, tak jak wcześniej uczynili to strażnicy Jerycha, i udali się we wskazanym przez nią kierunku. $Z$ tego pojedynczego zestawienia faktów jasno wynika, że to Rachab a nie mężczyźni, jest protagonistą wydarzeń.

19 I w tym względzie narrator akcentuje odwagę, zimną krew i iście żołnierską przebiegłość Rachab poprzez odpowiedni ton narracji i precyzyjnie dobraną terminologię. Kobieta ożywionym głosem informuje posłańców króla, że jej goście niedawno wyszli, zachęca mocno do rozpoczęcia natychmiastowego pościgu (hebr. mahēr «szybko, natychmiast, z pośpiechem») i wyraża żywe przekonanie, że pogoń za zbiegami będzie skuteczna (kî taśśî̀gum «żebyście ich pochwycili”»). Lektor narracji wie jednak, że wszystkie słowa Rachab i jej udawana postawa współpracy są zorientowane na odwrócenie uwagi żołnierzy od jej domu, w którym skrywają się zwiadowcy, dlatego też dowiaduje się z satysfakcją z następnego wiersza, że wysłannicy króla dali wiarę wyjaśnieniom Kananejki i rzucili się w pogoń w niewłaściwym kierunku $(2,7)$. 
nymi władcami i narodami, Rachab dostrzega realną szansę radykalnej zmiany swej dotychczasowej sytuacji. Legitymując się trzeźwością umysłu i umiejętnością wnikliwej obserwacji, a nade wszystko właściwej oceny ówczesnego kontekstu historycznego, Kananejka dochodzi do przekonania, że dni Jerycha i całego Kanaanu są już policzone. Panika, nerwowość i strach, jakie ogarnęły elitę rządzącą i mieszkańców miasta były dla niej ewidentną zapowiedzią i znakiem dokonujących się zmian. To dlatego postanawia wejść w kolaborację z nadchodzącym wojskiem Jozuego, aby zapewnić sobie i swym bliskim ocalenie oraz lepsze warunki życia w niedalekiej przyszłości. Rachab nie ma patriotycznych powinności wobec własnego narodu, który zepchnął ją na margines społeczny i zmusił do codziennej upokarzającej walki o przetrwanie. $Z$ tego względu z wyrachowaniem i obojętnością wprowadza w błąd królewskich posłańców, a jednocześnie daje schronienie przyszłym zdobywcom Jerycha.

Jako roztropna i doświadczona życiem niewiasta, Rachab wie jednak, że o lepsze jutro trzeba walczyć wytrwale i do końca, dlatego natychmiast po odejściu strażników Jerycha wykorzystuje wciąż trudną sytuację zwiadowców izraelskich i przystępuje do realizacji drugiej części swego mądrego planu. I na tym etapie widać jej niezwykłą odwagę i determinację w walce o lepszy byt swego rodu. Rachab prezentuje niezwykłe dla kobiety wyrachowanie, roztropność i przebiegłość, a także zdolność prowadzenia twardych, rzec by można, męskich pertraktacji, których owocem stanie się ocalenie jej rodziny oraz gwarancja odpowiedniego statusu społecznego w obrębie społeczności hebrajskich pokoleń po zdobyciu Palestyny. Kananejska nierządnica od razu daje do zrozumienia Izraelitom, że wie doskonale kim są i czego szukają w Jerycho. Ponadto popisuje się przed nimi rzeczową i trafną oceną sytuacji w mieście, a co najważniejsze dokładną i właściwą interpretacją ich niedawnej historii. Jak doświadczony teolog przeniknięty wiarą w moc Bożą, Rachab oznajmia zdumionym zwiadowcom, iż wie, że siłą izraelskich oddziałów jest JHWH, który już pokonał okolicznych władców, a niedługo doprowadzi do klęski Jerycha (2,8-11). Uznając strategiczną i militarną przewagę swych rozmówców oraz wieszcząc ich zwycięstwo w konfrontacji z mieszkańcami Jerycha, Rachab zyskuje ich przychylność w dalszych pertraktacjach. Równocześnie, jak wytrawny negocjator, Kananejka nie zdradza zwiadowcom faktu, iż niebezpieczeństwo, jakie czyhało na nich ze strony posłańców króla, zostało definitywnie zażegnane dzięki jej sprytnemu działaniu. W ten sposób ludzie Jozuego czuli się wciąż zależni od swej gospodyni, a zatem, chcąc nie chcąc, musieli brać pod uwagę jej zdanie i żądania ${ }^{20}$. Tymczasem Rachab posiadała jasno określony plan działa-

20 Zupełną zależność zwiadowców Jozuego od Rachab podkreśla w narracji kilka szczegółów: najpierw miejsce ich ukrycia (dach domu, 2,6), skąd nie było żadnej ucieczki; 
nia. W zamian za azyl w swym domu, domagała się więc obietnicy ocalenia jej rodu podczas inwazji na Jerycho popartej dodatkowo przysięgą na największą świętość Izraela, czyli na Boga JHWH, oraz wiarygodnego znaku $(2,12-13)^{21}$. Zdecydowanie niewiasty, która umiejętnie wykorzystuje niezwykłe okoliczności spotkania ze zwiadowcami Jozuego, a także jej doskonała znajomość ich niedawnej historii oraz mocy Boga, tak mocno udzieliła się wdzięcznym za okazaną pomoc Izraelitom, że nie tylko pod przysięgą zgodzili się na stawiane przez nią warunki, ale też ze swej strony dodali zapewnienie o wyjątkowo hojnym potraktowaniu kananejskiej kobiety po podboju miasta i ziem Kanaanu $(2,14)$. O wspaniałomyślności ich przysięgi świadczą użyte w tym miejscu terminy hebrajskie hesed i 'emet, które w Biblii są najpiękniejszym i najpełniejszym synonimem Bożej i ludzkiej życzliwości, łaski, dobroci, miłości i przebaczenia (hesed), a także prawdy, wierności, wiarygodności i trwałości ('emet). W konkretnym kontekście podboju Jerycha i całej Palestyny tak określona postawa Izraelitów wobec Rachab będzie oznaczać, że zyska status wolnego obywatela posiadającego własną ziemię i żyjącego pośrodku wspólnoty narodu wybranego (6,22-25). Jedynym warunkiem, jaki zwiadowcy postawili Rachab była dyskrecja wobec ich sekretnej misji oraz powziętego planu podboju Jerycha. Stanowczość kananejskiej niewiasty oraz wagę przysięgi zwiadowców potwierdza finał dialogu. Zwiadowcy zawierają z Rachab i jej bliskimi rodzaj dwustronnego przymierza, które ma zobowiązać obie strony do lojalnego wypełnienia powziętych postanowień. Rachab ma dotrzymać całkowitej tajemnicy odnośnie wizyty zwiadowców i zadbać o to, by w chwili szturmu na Jerycho wszyscy członkowie jej rodu byli wewnątrz jej domu, natomiast Izraelici zobowiązują się zachować ich wszystkich przy życiu. Potwierdzeniem tego specyficznego przymierza jest umówiony przez obie strony znak (sznur purpurowy), który ma stać się gwarancją ocalenia dla Rachab i jej bliskich, nato-

następnie obecność wysłańców króla znajdujących się w dolnej kondygnacji domu, a więc blokujących jego drzwi; w końcu zamknięcie bram miasta po wyjściu pościgu, co uniemożliwiało ucieczkę na zewnątrz Jerycha $(2,7)$. W tym świetle kolejny raz maluje się odwaga i zaradność Rachab, która doskonale radzi sobie w tym trudnym położeniu i pomaga uciekinierom przejść mur miasta przez okno swego domu. Jednocześnie narrator kolejny raz podkreśla jej desperację i życiowy spryt. Kananejka wykorzystuje niebezpieczeństwo grożące zwiadowcom, by wynegocjować korzystne warunki przymierza dla siebie i swej rodziny.

21 Narrator nie precyzuje, jakiego znaku zażądała Kananejka od zwiadowców. Odpowiadając na jej żądanie, Izraelici składają przysięgę na swoje życie, że ocalą wszystkich jej domowników, a po zdobyciu Kanaanu okażą jej życzliwość i wiernie dopełnią przysięgi $(2,14)$. Na podstawie dalszych działań Rachab, które okazały się zbawienne dla ludzi Jozuego (2,15-16.22-23), należy sądzić, że Kananejka była usatysfakcjonowana tymi zapewnieniami. 
miast przypomnieniem i zobowiązaniem dla szturmujących Izraelitów. Sznur ten został wywieszony przez kobietę w momencie ucieczki zwiadowców, stając się widocznym dla stron przymierza potwierdzeniem zawartej pod przysięgą umowy. W chwili jego zawarcia był symbolem ocalenia Izraelitów (zwiadowcy uciekli spuszczeni przez Rachab po sznurze przez okno jej domu, por. 2,15), zapowiadając jednocześnie ocalenie wszystkich domowników w chwili ataku Jozuego oraz ich nowe i lepsze życie (6,22-25).

Niezwykła mądrość i życiowe doświadczenie Rachab jest widoczne również w ostatniej fazie epizodu z wywiadowcami. W 2,15-16 narrator opisuje drobiazgowo sposób, w jaki kananejska kobieta ratuje życie zwiadowcom Jozuego. Najpierw umożliwia im niepostrzeżenie zbiec z miasta, spuszczając ich z okna swojego domu umiejscowionego w miejskim murze. Następnie dokładnie instruuje co do dalszych kroków, które winni podjąć, aby bezpiecznie wrócić do swego obozu. Rachab podaje swym gościom kierunek ucieczki, miejsce schronienia i czas konieczny do zmylenia pogoni $(2,16)$. W 2,22-23 narrator relacjonuje, że zwiadowcy postapili dokładnie według wskazówek Rachab, przez co ocalili życie i bez przeszkód wrócili do Jozuego, zdając mu precyzyjne sprawozdanie z przebiegu swej misji $(2,24)$. Rachab jest zatem ukazana jako główny bohater całego epizodu, który w każdym podjętym przez siebie działaniu wykazuje się zdecydowaniem, trzeźwością i trafnością oceny, życiowym doświadczeniem i wielkim sprytem. Wszystkie te przymioty oraz postawy pozwalają jej na zdominowanie męskich bohaterów narracji, zarówno wysłańców króla Jerycha jak i wywiadowców Jozuego, a w konsekwencji dają jej ocalenie podczas podboju miasta oraz materialną i społeczną niezależność w nowej epoce.

Historia Rachab jest jedną z najlepszych ilustracji biblijnej koncepcji wiary. Wiara $\mathrm{w}$ tradycjach starotestamentowych nie jest nigdy kwestią tylko duchowego i emocjonalnego przeżywania własnej relacji z Bogiem czy też czysto teoretycznego podejścia rozumowego do tajemnicy Jego istnienia i aktywności zbawczej. Wiara w konwencji biblijnej ma również mocny wymiar praktyczny, jest bliską osobową więzią z Bogiem, która ma bezpośrednie przełożenie na codzienne życie i postępowanie. Jak wymownie demonstruje przykład nawróconej na monoteizm jahwistyczny Kananejki Rachab, jednym z istotnych komponentów wiary jest także umiejętność podejmowania przemyślanych i mądrych decyzji, a także zdolność radzenia sobie nawet w najtrudniejszych próbach życiowych. Jest to możliwe, gdyż światłem i siłą do tak odważnego przezwyciężania niebezpieczeństw i niestrudzonego dążenia do prawdy oraz osiągnięcia godziwych warunków materialnych i społecznych jest Bóg JHWH. Jemu bliski jest każdy człowiek, Jemu poddane są wszystkie moce i wszyscy ludzie, ponieważ jest Panem wysoko na niebie i nisko na ziemi. Szczególne zaś miejsce w Bożej ekonomii zbawienia zajmują ludzie wierzący oraz niespra- 
wiedliwie uciskani. Oni zawsze, tak jak Rachab i Izraelici epoki Jozuego, będą mogli liczyć na Jego interwencję zbawczą.

\section{Bibiografia}

Boling, R., Wright, G., Joshua: A New Translation with Notes and Commentary (AB 6; New Haven 2008).

Butler, T., Joshua (WBC 7; Dallas 1998).

Howard, D., Joshua (NAC 5; Nashville 1998).

Floss, J., Kunden oder Kundschafter? Literaturwissenschaftliche Untersuchung zu Jos 2. I. Text, Schichtung, Überlieferung (ATSAT 16; St. Ottilien 1982).

Floss, J., Kunden oder Kundschafter? Literaturwissenschaftliche Untersuchung zu Jos 2. II. Komposition, Redaktion, Intention (ATSAT 26; St. Ottilien 1986).

Hubbard, R., Joshua (NIVAC; Grand Rapids 2009).

Keil, C., Delitzsch, F., Commentary on the Old Testament. Joshua (Peabody 1996).

Noort, E., Das Buch Josua: Forschungsgeschichte und Problemfelder (Darmstadt 1998).

Woudstra, M. H., The Book of Joshua (NICOT; Grand Rapids 1981). 